\title{
レーザ顕微鏡で生物の3 次元を見る
}

\section{倉田博之, 高松哲郎}

京都府立医科大学第 2 病理

生物学の進歩に従来の光学顕微鏡の果たした役割の大 きさについては異論のないところである。しかし，我々 研究者の欲求はとどまることがない，たとえば，生物の 微細な 3 次元構造を観察したい，それも可能ならば生き たままの状態で，といら欲求もそのよい例であろう.

ところで, 試料を一様燳明する従来の光学顕微鏡で は結像した画像のコントラストが低く,像の重なりなど のため, 光軸に沿った位置関係を判断し難い、また，電 子顕微鏡を用いると確かに微細な構造観察はできるが， 連続切片作製による 3 次元再構築は多大な労力を必要と するし，生体のダイナミックな変化を捉えることはほと んど不可能である.

これに対して, Minsky のアイデア(1)を光学技術と電 子制御技術の進歩によって実現した共焦点レーザ走查顕 微鏡（以下，レーザ顕微鏡）は，その高いコントラスト 之高分解能によって, (1)従来の光学顕微鏡と電子顕微鏡 の間を補完できる分解能が期待できる, (2)切片を作製せ ずに生きた細胞や組織の光学的断層像がとれる, (3)歪み が非常に少ない画像をとることが可能であるため簡単な 画像処理で精度の高い立体構築ができるなど，「細胞や 組織位する光 $\mathrm{CT} 」$ と言光る性質をもつ 2 2 4). まさ に，生物学者にとって夢を実現できる装置と言兄よう。 以下に, この顕微鏡の簡単な原理, および筆者らの教室 でレーザ顕微鏡を用いて 3 次元観察した例を紹介する.

\section{原理と光路}

まず「共焦点」とはいかなるものであろらか．図1を 見ていただきたい.ダイクロイック・ミラー*によって 反射された励起光は対物レンズによって標本内の焦点に 収束する，その焦点から生じた螢光は, 長波長であるた

*ある波長より短い波長の光は反射（ないし透過）させ，長い 波長の光は反対に透過（ないし反射）させるビーム・スプリッ タのこと.

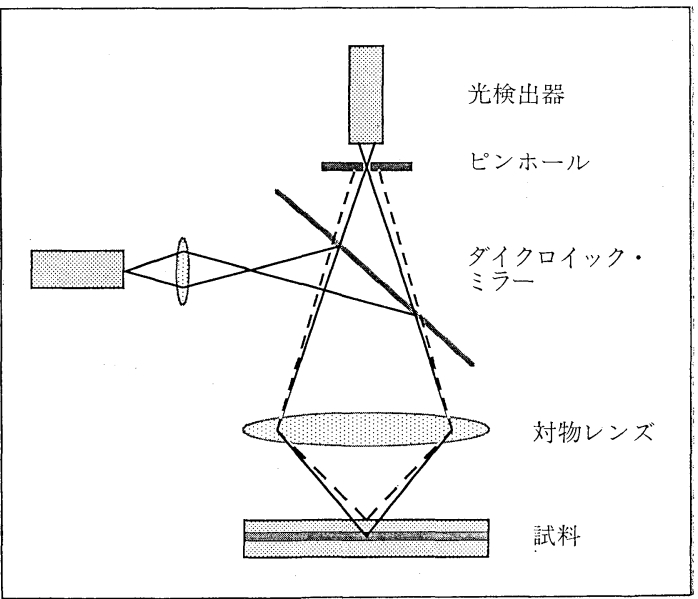

図 1 共焦点螢光顕微鏡

対物レンズによって収束したレーザ光が標本を励起する時，焦 点からの螢光 (実線) は光検出器の前に置かれた共焦点ピンホ ールを通過するが，焦点以外からの營光（破線）は通過できな い，つまり，焦点からの情報だけが画像となる.

め今度はダイクロイック・ミラーを通過し，共焦点位置 のピンホールを通って光検出器に届く.この時, たとえ 図 1 の破線に示すような焦点から外れたところからの螢 光が存在していても，ピンホールによって遮られ，光検 出器には届かない，つまり，焦点からの情報だけによる コントラストの良い像が得られることになる.

ここで, 励起光でつくられるスポットは小さいほど高 い分解能が得られるわけであるが，励起光をレーザ光と するとどらなるであろらか。レーザ光は高輝度で波長が 一定し位相の揃った，すなわちコヒーレントな光であ る. そのため対物レンズで Huygens-Fresnel の理論值 に近い小さなスポット[焦点面上では半径が $0.61 \lambda /$ (開 口数), 光軸上では $2 \lambda /$ (開口数) ${ }^{2}$ まで絞ることが可能 となる. 主としてこのスポット中の螢光物質の久が励起 され光を発するが，この小さなスポットから出た螢光は 点であって像ではない，そこで，2つのスキャナーを用 


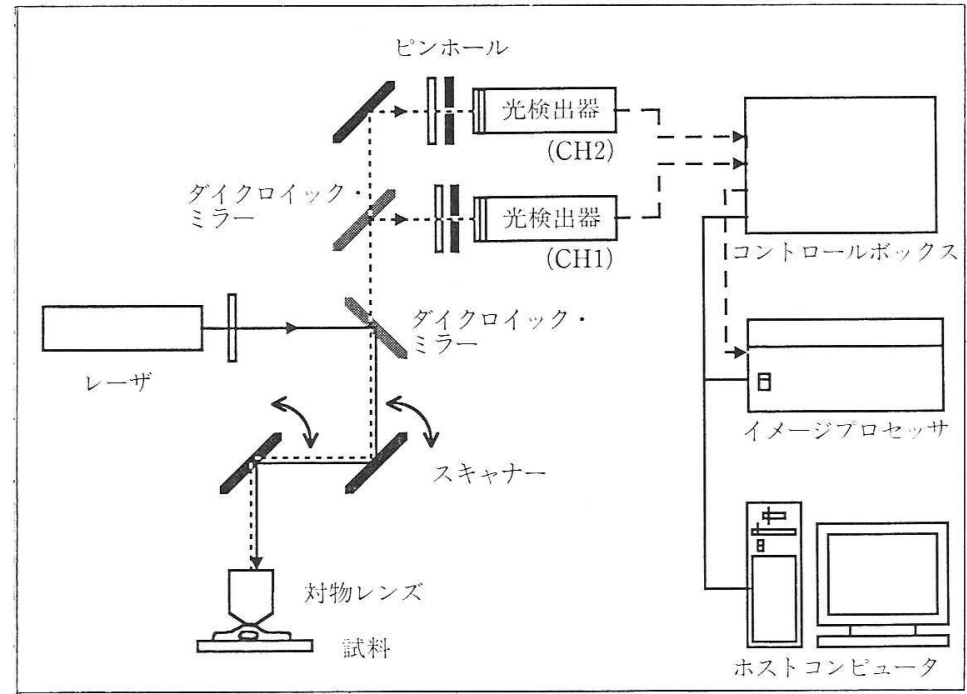

図 2 日共焦点レーザ走査螢光顕微鏡（正立型）

いて $X Y$ 軸方向にスポットを走查し，その位置情報から 相当するピクセルに光検出器で感知した螢光量に応じた 輝度を入力する. こうして 1 フレーム分走査が終わるこ とによって画像を得ることができる（図 2).

このレーザ顕微鏡は，これまでのいかなる光学顕微鏡 で達成されたよりも飛躍的に浅い焦点深度をもら, また 解像力も $\mathrm{Abbe}$ の理論で規定されたものより倍近く改 善され(5), 焦点面だけでなく光軸に沿ってのコントラス
トを高めた光学顕微鏡ということに なる、また、このコントラストの良 さは 3 次元構造を理解する上で素晴 らしい手段となる。つまり，レーザ 顕微鏡を用いて光学的にスライスし てやれば,アーティファクトのな い, 連続性が保た机た 3 次元像がつ くられ，内部構造の立体関係は一目 膫然となる。さらに, 生さた細胞中 でゲル状に存在するオルガネラ, 細 胞内骨格などの内部構造は，通常の 光学顕微鏡にとっては非常にコント ラストの悪いものであったが, コン トラストが上がることによって，細 胞内の情報を断層像として得ること が可能となり，ダイナミックな変化をも観察でさるよら になる・

\section{生物への応用}

1. 光学的断層像がとれる

ヒト免疫不全ウイルス Human Immunodeficiency Virus type-1: (HIV-1) の転写後調節因子である Rev の 局在を知る目的で, その発現プラスミドを $\operatorname{COS}-7$ 細胞

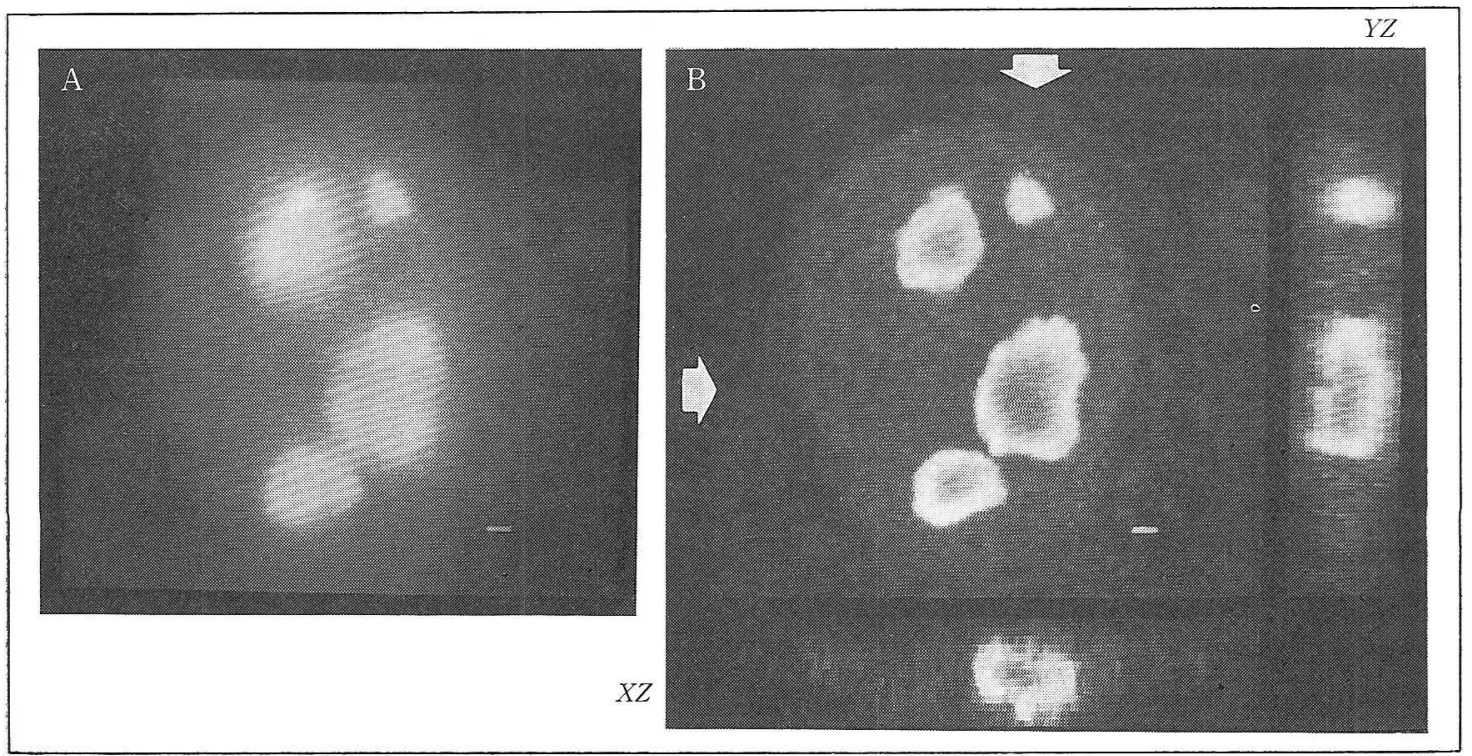

\section{図 3- HIV-1 の転写後調節因子 Rev の局在}

rev の発現プラスミドをCOS-7 細胞にトランスフェクトし，14 時閒後に螢光抗体法で染色した. A : 非共焦点像，B：共焦点像. 14 時間後では，rev 蛋白は核小体周囲にとどまり，核小体内部には存在しない. 対物レンズ Olympus SPlanApo 100 (NA=1.4), Olympus LSM-GB 使用. 
ルトランスフェクトして 3 次元観察した ${ }^{(6)}$. 図 3 は, ト ランスフェクトして, 14 時間後に固定し, 抗 rev 蛋白 抗体を用いて FITC (fluorescein isothiocyanate) 標識 したものである。共焦点位置のピンホールを使用しない で観察した図 3-A に比較して，共焦点像（図 3-B）では 核小体の周辺に rev 蛋白が存在することが明らかであ る.また， $Z$ 軸 (深さ方向) の位置をずらしながら連続 的に画像を入力した後, 矢印の部位に和忷る $X Z$ 方向お よび $Y Z$ 方向の断面を再構築した画像も示す.このよら k 3 方向からの断層像を作成すると， 3 次元構造がより 理解しやすくなる.

\section{2. 立体的な計測ができる}

染色体の数にセントロメアの数は対応しており, セン トロメアの数を正確にカウントできれば，間期の核でも 染色体の数を知ることができる。セントロメア領域に特 異的な抗体をもつ CREST 症候群の患者血清を用いて 正常の間期線維芽細胞を染色し，レーザ顕微鏡で観察し

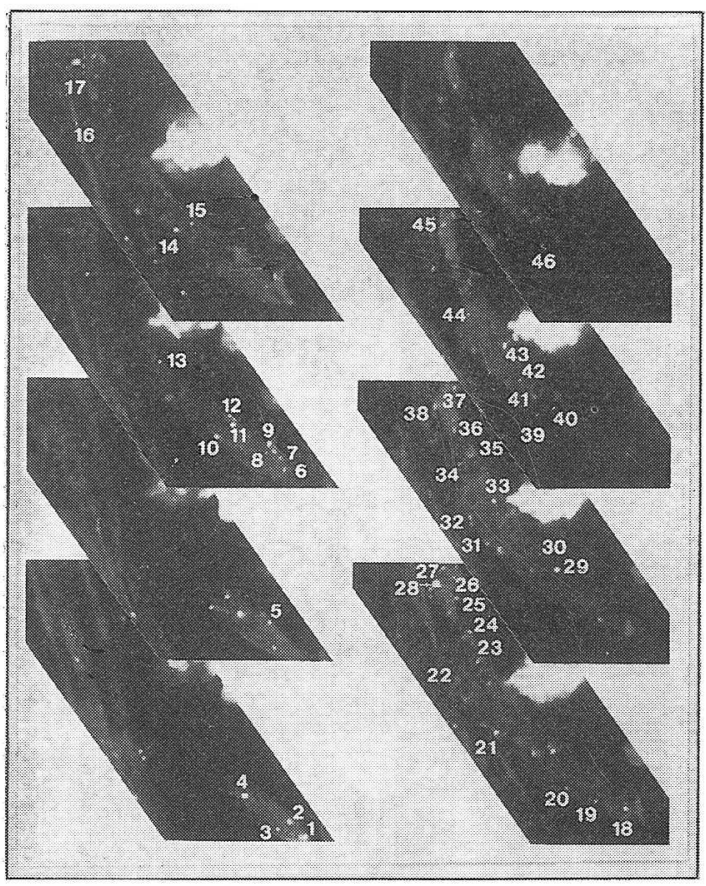

図 4 䁌期核におけるセントロメア数の計測 間期ヒト線維第細胞を，セントロメア領域に対する CREST 症 候群の患者血清を用いて FITC 標識した. 核の連続光学的断層 像 (1 $\mu \mathrm{m}$ 間隔) においてセントロメア数の計測を行なってい る. 複数の断層像にラベルがわたるとさは，一番明るいところ に番号が示してある. 対物レンズ Olympus SPlanApo×60 (NA=1.4, 油侵), Olympus LSM-GB 使用.
たのが図 4 である．促来行なわれてきた 2 次元に展開し て観察する方法に比較して，深さ方向の分解能があるた め上下に重なった陽性部分も別々に認識でき,さらに核 内に広がったまま観察できるので，互いの位置関係につ いて 3 次元的な解析が可能となる(7).この方法は, fluorescence in situ hybridization (FISH) 法によって, 特定の染色体の数を間期の核の中でカウントする場合な ぞにも応用できる。

\section{3. 細胞内のタ゚イナミックな変化をとらえる}

細胞内カルシウムシグナリングとして，局所的に高い カルシウム濃度を示す部位が出現し, 周困に伝わってい くカルシウム波といら現象が知られているが、レーザ顕 微鏡を用いてこの現象を高い分解能でとらえることがで きる.さらに, レーザ顕微鏡から得られた画像の輝度 は, 一定の厚さの光学的断面に由来するので, 細胞の部 位による厚みの違いに影響されない。このことは, 特定 の物質を定量的に染色することさえできれば，一定の厚 さをもつセルを利用して測定する分光光度計の測定原理 と同じとなり, 得られる螢光輝度が直接物質の濃度を反 映していると考えられる(8). さらに最近では光学系の改 良から, 近紫外域に括いてもレーザ顕微鏡が利用でさる ようになり(9), ratio 法が使觉るカルンウムイオン指示 薬 indo-1 や DNA の A-T ペアに特異的に結合する螢 光試薬 DAPI といった色素が使用でさるよらになって きた。

このよらな背景のもとに, マスト細胞をコンパウンド 48/80 の刺激によってヒスタミンの脱顆粒を起こさせた 際生じてくるカルシウム波が，1つの光学的切片の中を 伝播する様子を観察した (10) (図 5). 焦点面でのフレー ムスキャン像（図 5-A）加, 刺激後の細胞質と核内の カルシウム濃度上昇の時間経過の相違や, 細胞質に比較 して核内がより高い濃度になることがわかる，さらに高 い時間分解能で観察するため, 局所刺激を与皇たときの $X-t$ スキャン（ $Y$ 軸方向の走查を止め， $X$ 軸に沿った同 じライン上を繰り返し走查する方法）を図 5-B に示す. 刺激部位に近い細胞質から核を通過して反対側の細胞質 へ伝播するカルシウム波の時間経過が明瞭にとらえられ ている. 屯た, 刺激後に和ける細胞内カルシウムイオン 濃度の上昇に従って生じるアクチンフィラメントの変化 を立体観察した結果 ${ }^{(11)}$ (図 5-C，D），刺激前（図 5-C） 

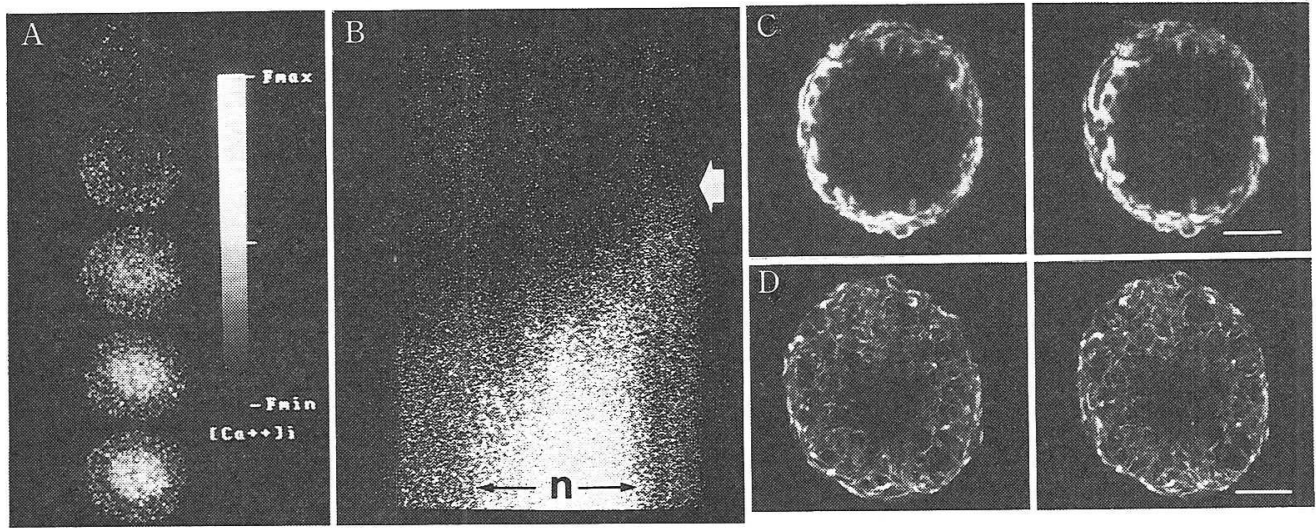

図 5 曰 マスト細胞の脱顆粒に伴うカルシウムイオン動態およびアクチンフィラメントの 3 次元構造変化

A : 焦点面でのフレーム走査画像. コンパウンド $48 / 80$ を灌流液中に加壳てマスト細胞全体を刺激し，80ミリ秒毎に光学断層像を 得た。刺激前は低かった細胞内カルシウムイオン濃度 $\left[\mathrm{Ca}^{2+}\right]_{\mathrm{i}}$ が，刺激後では細胞質，核内ともに上年し，この核内の上昇は約 2 分 間持続した. カルシウム指示薬は fluo 3 .

$B: X-t$ 走査像. $\left[\mathrm{Ca}^{2+}\right]_{\mathrm{i}}$ をより高い時間分解能で解析するため, マイクロピペットを用いてコンパウンド 48/80の局所刺激(太矢 印）を行なった。刺激側の細胞質から $\left[\mathrm{Ca}^{2+}\right]_{\mathrm{i}}$ が上昇し，核内を通過して反対側に達するカルシウム波を観察できた。横軸はX軸，

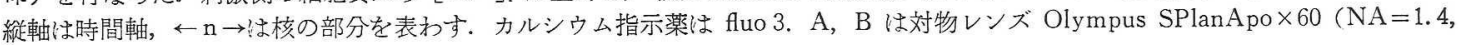
油侵), Olympus LSM-GI 使用.

$\mathrm{C}:$ 刺澈前. 細胞膜直下にアクチンフィラィントは限局している.

D : 刺激後. アクチンフィラメントが細胞内顆粒を包み込むように変化している．C，Dとも光軸方向に細胞の赤道付近を $0.3 \mu \mathrm{m}$ 毎, 20 枚の画像から図6に示寸画像処理法を用いて再構築した立体視像である.水平バーは $5 \mu \mathrm{m}$.

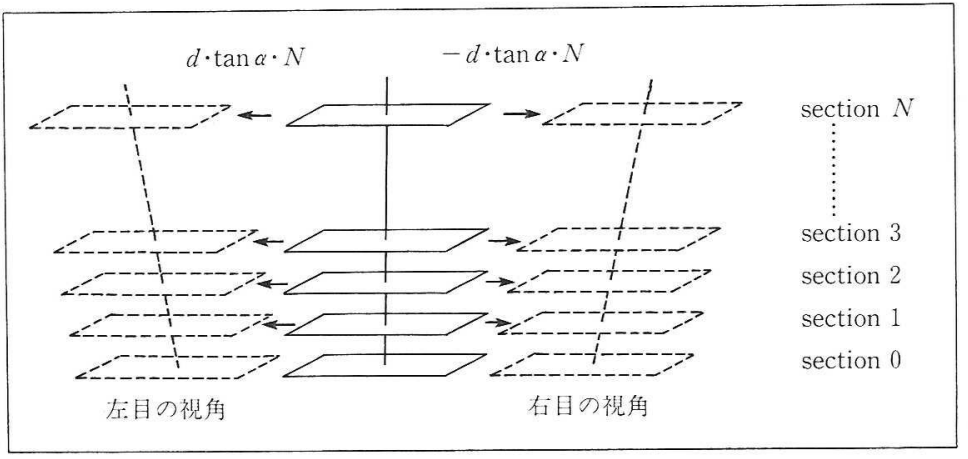

図 6日立体視像の作成方法

標本ステージを一定の間隔で上下させて得た連続画像を，視角に沿って左右にシフト させながら積算していく. $(N+1)$ 番目の画像をシフトさせる距離は，画像間隔を $d$, 視角を $\alpha$ とすると $d \cdot \tan \alpha \cdot N$ である. 画像の加算には，シフト後同じ座標にくるピク セルのらち最大の值を出力する方法と 16 ビットのフレームバッファにすべての画像を 加算した後，目的とした物質が一番よく観察できる 8 ビットを選択出力する方法があ る.

では細胞膜直下に限局していたアクチンフィラメント が，刺激後細胞内の分泌顆粒を包み込むように局在を变 光（図 5-D)，ダイナミックな変化が細胞内骨格にも生 じていることがわかった。これらの立体視は，レーザ顕 微鏡から得られる画像に歪みがきわめて少ないため, 図
6 のよらな簡単な画像処理で得られ $ろ^{(4)}$.このよらに, レーザ顕微鏡は 細胞内のダイナミックな生理的ある いは構造的変化を, 細胞機能に関連 づけてとらえることが可能である.

以上，生物を対象としたレーザ顕 微鏡を用いての 3 次元観察について 実例を挙げながら述べた、本稿では とり上げなかったが，最近ではレー ザ顕微鏡より 1 桁分解能の高いニア ーフィールド影微鏡も開発され，光 学顕徴鏡の生物への応用はますます 広がっている.生物系研究者にとっ て，今後ともまったく目の離せない分野である。

\section{文献}

1) M. Minsky : U.S. Patent $\$ 3013467$, microscopic apparatus, 1957.

2) T. Wilson \& C. Sheppard : "Theoy and Practice of Scan. 
ning Optical Microscope", Academic Press, London (1984).

3) G. J. Brakenhoff, H. T. M. van der Voort, E. A. van Spronsen, W. A. M. Linnemans \& N. Nanninga: Nature, 317, 748 (1985).

4) T. Takamatsu \& S. Fujita : J. Microsc., 149, 167 (1988).

5) O. Nakamura \& S. Kawata: J. Opt. Soc. Am. A., 7, 522 (1990).

6) Y. Miyazaki, T. Takamatsu, T. Nosaka, S. Fujita \& M. Hatanaka : FEBS Lett., 305, 1 (1992).

7) H.Sugihara, K. Katsura, T. Takamatsu \& S.Fujita :
Histochem. J., 24, 532 (1992).

8) T. Takamatsu, T. Minamikawa, H. Kawachi \& S. Fujita: Cell. Struct. Func., 16, 341 (1991).

9) T. Minamikawa, T. Takamatsu, S. Fushiki \& S. Fujita : Micron, 24, 551 (1993).

10) S. Katagiri, T. Takamatsu, T. Minamikawa \& S. Fujita : FEBS Lett., 334, 343 (1993).

11) S. Katagiri, T. Takamatsu, T. Minamikawa \& S. Fujita : Bioimages, 2, 119 (1994).

\section{プロ フ ィ ル}

野 瀬 清 (Kiyoshi Nose) 昭和18年 1 月 25 日生 $<$ 略歴 $>$ 昭和 40 年東京大学薬 学部製薬化学科卒業 $/ 45$ 年同大学医科学 研究所助手 $/ 51$ 年富山医科楽科大学助教 授 $/ 60$ 年東京大学医科学研究所助教授 $/$ 平成 4 年昭和大学薬学部教授, 現在にい たるく研究テーマと抱負>活性酸素によ る遗伝子発現, 増殖制御の分子機構. 特 に細胞老化との関連く趣味 > 釣り, サイ クリング

野々山松雄 (Matsuo Nonoyama) 昭 和 19 年 6 月 24 日生 $<$ 略歴>昭和 42 年名古 屋大学理学部化学科卒業 $/ 44$ 年同大学大 学院修士課程修了/同年同理学部化学科 助手/平成 3 年分子科学研究所錯体化学 実験施設助手 $/ 4$ 年名古屋大学理学部化 学科助手, 現在にいたるく研究テーマと 抱負 $>$ 新奇な錯体の合成. 失敗の山の中 から一粒のダイヤモンドを探した時の心 境を味わうのを楽しみにしています

春山 英幸 (Hideyuki Haruyama) 昭 和30年 1 月 26 日生<略歴>1978年東京大 学薬学部製薬化学科卒業 $/ 1980$ 年同大学 大学院楽学系研究科修士課程修了/同年 三共(株)入社, 現在にいたる. 分析代謝 研究所副主任研究員. 1986年薬博. この 間, 1986 88年スイス連邦工科大学 (K. Wüthrich 教授) 博士研究員 <研究テー マと抱負 $>$ NMRによる複雑な天然有機 化合物およびタンパク質の構造解析. 昔 からずっと薬物と受容体が相互作用する 場を丸単位で見たいと思ってきました。
今やそれが現実的なテーマとなって，と ても exciting ですく趣味〉ブラスアン サンブル，ただし最近は聞くばかり

平井 伸博 (Nobuhiro Hirai) Vol.30, No.2, p. 135 参照

藤木 博太 (Hirota Fujiki) 昭和11年 11 月 7 日生 $<$ 略歴>昭和36年九州大学医 学部卒業後, 西独マックス・プランク生 化学研究所, 米国ハーバード大学生物学 研究所を経て, 昭和 52 年国立がんセンタ 一研究所室長 $/ 61$ 年同部長 /平成 5 年埼 玉県立がんセンター研究所副所長, 現在 にいたるく研究テーマと抱負〉ヒトの発 がんプロモーションとがんの化学予防の 研究

正木 武治 (Takeharu Masaki) 昭和 16 年 10 月 3 日生 $<$ 略歴>昭和 40 年茨城大 学農学部農芸化学科卒業 $/ 41$ 年同大学農 学部農芸化学科教務員 $/ 44$ 年同助手 $/$ 平 成 6 年同助教授を経て教授, 現在にいた るく研究テーマと抱目〉厳密な特異性を もつプロテアーゼの検索とその酵素化学 的性質拉よび利用く趣味>野球, 卓球

三浦 弘之 (Hiroyuki Miura) 昭和 6 年 4 月 30 日生 $<$ 略歴 $>$ 昭和 30 年带広畜産 大学畜産学部酪農学科卒業 /同年同酪農 学科副手 $/ 34$ 年同助手 $/ 50$ 年同教授, 現 在にいたるく研究テーマと抱負 > 食肉産 業廃裹物の高度利用に関する問題, 食肉 の肉質改善〈趣味 $>$ テニス, 水泳
三上 正幸 (Masayuki Mikami) 昭和 16 年 9 月 24 日生 $<$ 略歴 $>$ 昭和 40 年帯広畜 産大学畜産学部酪農学科卒業 $/ 42$ 年北海 道大学大学院修士課程修了/同年帯広畜 産大学 助手 $/ 48$ 年 同講師 $/ 53$ 年同助教 授/平成 4 年同教授, 現在にいたるく研 究テーマと抱負 $>$ 食肉の熟成とうまみ成 分く趣味〉山スキー, 山歩き, スキー

吉岡 博人 (Hiroto Yoshioka) 昭和 25 年 9 月 5 日生 $<$ 略歴>昭和 49 年大阪府 立大学農学部園芸農学科卒業 $/ 55$ 年同大 学大学院 農学研究科博士課程 修了（農 博) $/ 57$ 年農林水産省果樹試験場盛岡 支 場勤務 /平成 6 年同試験場企画連絡室, 現在にいたるく研究テーマと抱負〉果実 の成熟に伴う 品質形成機構の 解明＜趣 味>ハイキング, スキー

吉田 久美 (Kumi Yoshida) 昭和 33 年 2 月 12 日生 $<$ 略歴 $>$ 昭和 55 年名古屋大 学農学部食品工業化学科卒業 $/ 57$ 年同大 学大学院農学研究科博士前期修了/同年 天野製薬(株)研究部勤務 $/ 63$ 年椙山女学 園大学生活科学部食品栄養学科助手, 現 在にいたるく研究テーマと抱負>花色素 アントシアニンの有機化学的, 食品化学 的研究. 花が咲くといらことは色素の面 からだけでなく, 生理の面からもとても 興味深く，今後は植物全体をながめて花 の研究をしたいと思っていますく趣味〉 乱読, スポーツ各種 (水泳, スキー, テ =ス) 